\title{
Geolithology and provenance of materials of some historical buildings and monuments in the centre of Florence (Italy)
}

1 Earth Sciences Department - University of Florence, Via G. La Pira, 4, 50121 Florence, Italy.

2 C.N.R.- I.C.V.C.B., Via degli Alfani, 74, 50121 Florence, Italy.

Two very important historical areas have been considered in this work. Piazza della Signoria with the Palazzo Vecchio and many other outstanding buildings, is a typical example of the use of sandstone materials characteristic of the Florentine area; Piazza del Duomo with the Cathedral of Santa Maria del Fiore standing in the middle is, on the other hand, an example of other equally typical lithotypes such as the "white" marble and the "red" and "green" "marbles" that decorate the Cathedral. A detailed study as well as the relief and the mapping of the historical buildings in Piazza della Signoria and of the Cathedral of Santa Maria del Fiore, have led to the description of the materials that make them up as well as to the establishment of their quarry provenance.

\section{Historical introduction to the Florentine centre}

Buildings in the centre of Florence range in time from the Middle Ages to the Renaissance up to the nineteenth century and record the history of this town.

Florence started expanding and increasing in importance at the end of the 12th century with the construction of new city walls, reaching the level of other large European cities in the 13th century As its population increased, the Florentines began more and more to inhabit larger public buildings which were often built leaning one against the other due to a lack of space. The wealthy higher social classes exhibited their economic power by having tall towers built where they could seek protection from the violence of private revenges and from the struggle between factions. Churches were generally built in isolated places.

In Dante's times a new political order led to other changes: first of all, towers were demolished and new public buildings were built worthy of a own centre that had become one of the largest and richest in Europe. The Palazzo Vecchio was built as well as the Loggia dei Priori (today known as the Loggia dei Lanzi) and many other mansions belonging to the emerging artisan middle class. On September 8, 1296, the first stone was set for the Cathedral of Santa Maria del Fiore which was not dedicated and structurally completed until 1436. The Orsanmichele rose (entirely built in stone) destined to the wheat market became one of the most beautiful churches in the historical centre after 1350 .

Although in the late 14th century many buildings had bestowed a rather uniform, anonymous appearance on the city with their flat even façades. During the 15 th century, the construction of privately owned buildings and original mansions started to give the town a more diversified aspect. The façades of the latter generally reached the third floor, were symmetrical and concentrated on a single entrance, leading to the inside; their covering was stone carved such as ashlar or plaster; these two types of styles were often used together to point out the differences between the storeys of the building. These mansions stood along the narrow streets of the medieval town and almost none of them faced the already existing squares.

At the beginning of the 16th century, the concentration of buildings in some streets had increased to the point of changing the morphology of the quarter.

From the 12th century the main stone materials used in Florentine architecture were two sandstones: Pietraforte and Pietra Serena; while various types of marbles, serpentinites, bricks and plasters were also used to reach special chromatic effects. Pietra Serena was mainly used for decorative purposes, while Pietraforte was mostly used during the Middle Ages in the construction of the bearing structures of buildings and as a sheathing during the Renaissance (AA. VV., 1993, Bargellini et al., 1970).

\section{Piazza della Signoria}

Piazza della Signoria, one of the most beautiful squares in Florence, hosts the Palazzo Vecchio, the seat of the present City Hall. The area covered by the square has very ancient roots, in fact excavations made in 1974 and more recently, when the square was repaved between 1982 and 1989, have even revealed important original remains of the former imperial Roman city that lay in its place. The original square was modified during the medieval period and later between the 11th and 14th centuries, when many towers and houses were demolished after the Guelf victory against the Ghibelline faction; at the end of the 13th century, the Palazzo dei Priori (now the Palazzo Vecchio) was built by Arnolfo di Cambio. In 1342, the Duke of Athens gave a new arrangement to the square ordering the demolition of some buildings to create an open space in front of the Palazzo Vecchio. During the florentine republic, the Marzocco and the Giuditta sculptures were introduced by Donatello and the David by Michelangiolo (Allegri and Cecchi, 1980). During the Medici dynasty, important decorative changes were made to the square such as the Fonte di Nettuno by Bartolommeo Ammannati and the Monumento Equestre a Cosimo I by Giambologna.

\section{Materials making up the buildings and the pavement of Piazza della Signoria}

The materials mainly used in Florentine architecture are those that can most easily be found in the surroundings of the city such as the Pietra Serena sandstone, cropping out in the hills near Fiesole, north of the city and Pietraforte which are found in abundance in the hills south of the city. 


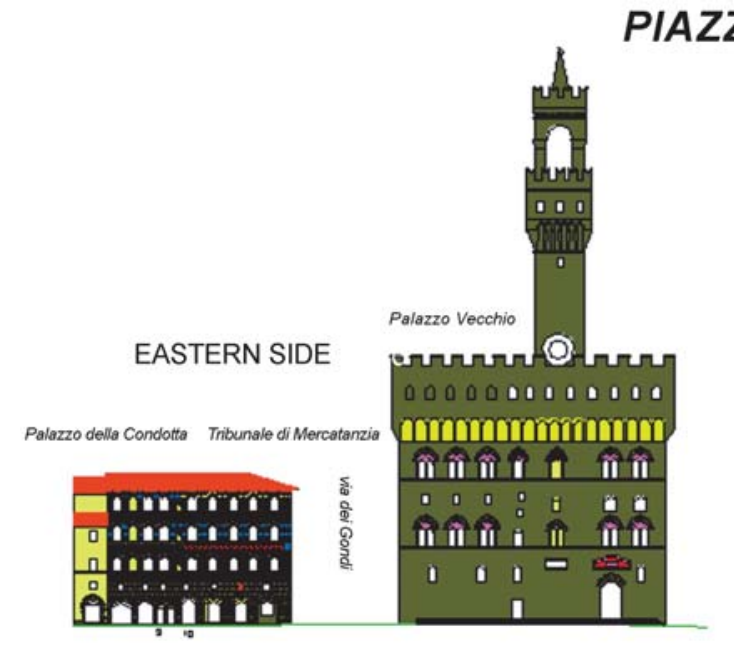

NORTHERN SIDE

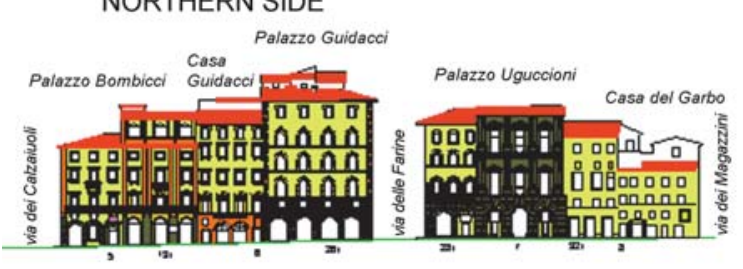

ZA DELLA SIGNORIA

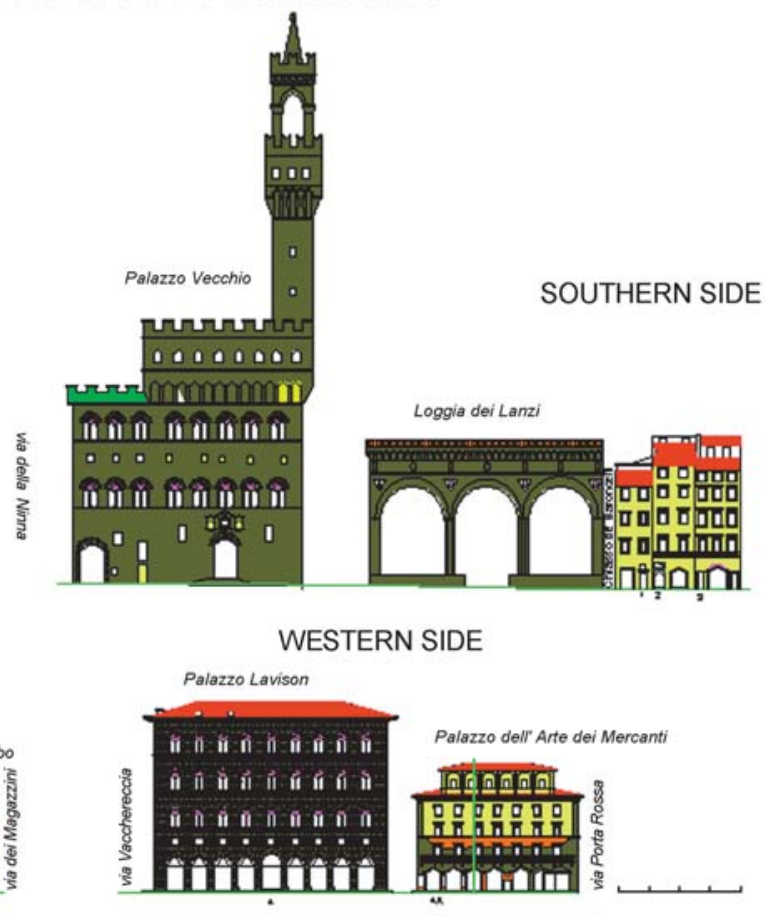

Figure 1 Prospect of the Piazza Signoria: view of the materials making up the buildings.

The mansions standing in the Piazza della Signoria (Bargellini and Guarnieri, 1985-87) and especially those of medieval age consist mainly of Pietraforte with portions decorated with Pietra Serena. The most deteriorated parts have either been replaced during the centuries or rebuilt using mortars that imitate the stone (artificial Pietraforte or artificial Pietra Serena) or using decorated plasters. The square also shows good examples of these types of operations. The buildings of lesser importance in the square are covered instead with common plasters.

Starting from the eastern part of the square in a clockwise direction, the first building one sees is the Palazzo della Condotta (13th-14th century), built in Pietraforte, painted Pietraforte in the upper part, with common plaster all over the left side and brick on the roof and in the coats of arms. Close to it is the Palazzo del Tribunale di Mercatanzia (dating from the second half of 14th century), built exactly as the former one in Pietraforte, painted Pietraforte, common plaster and brick. Next, the Palazzo Vecchio (13th-14th century) (Cecchi, 1995) present City Hall and the seat of the Palazzo Vecchio Museum and a laboratory for the restoration of tapestries of the Opificio delle Pietre Dure. It was built by Arnolfo di Cambio with a façade consisting almost entirely of Pietraforte. Then one sees the Loggia dei Lanzi (14th century), an open air gallery completed

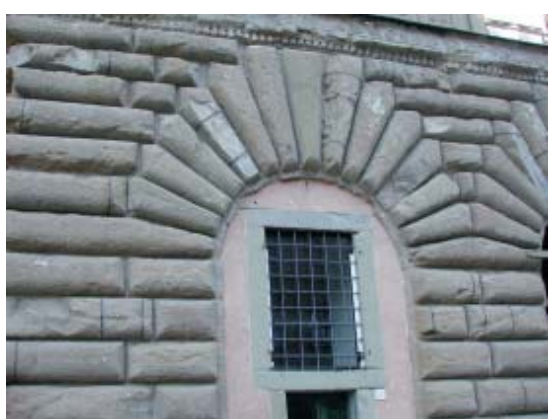

Figure 2 Piazza della Signoria: a particular of a building decoration in Pietra Serena and ashlars in Pietraforte. by the architects Benci di Cioni, Simone Talenti and Taddeo Ristori and entirely built in Pietraforte, except for the balustrade on the roof made of Pietra Serena and the coats of arms which are in glazed earthenware and marble. The houses standing in a row (14th century) presently used as restaurants, dwellings or offices are mostly covered with common plaster and artificial Pietra Serena; Pietraforte is present along the balconies and windows and marble decorations are on the arch of the main door. Following is the Palazzo Lavison (1869-1871), the present seat of the Assicurazioni Generali, shops and coffee shops, built by the architect Giuseppe Landi, is entirely in Pietraforte with statuario marble decorations around the mullioned windows. The building of the Arte dei Mercanti (14th-19th century), nowadays hosting shops and offices, has undergone many adaptations throughout the centuries. It was covered with common plaster in the higher part of its façade and with Pietraforte and Pietra Serena in the lower part; artificial Pietraforte and artificial Pietra Serena are present in the decorative elements. Palazzo Bombicci (18th century), nowadays hosting the Cassa di Risparmio di Firenze and the Alberto della Ragione Art Collection as well as a café, attributed to Bernardo Fallani, shows common plaster and Pietraforte on the façade, artificial Pietraforte, artificial Pietra Serena, Pietra Serena and statuario marble in its decorative elements. The Casa Guidacci (built in the 13th century and later remodelled) nowadays hosts the seat of the Banca Toscana and private homes. It has common plaster on the façade and artificial Pietraforte as well as parts in Pietra Serena and artificial Pietra Serena. The Palazzo Guidacci (13th-19th century), nowadays the location of the Banco Ambrosiano Veneto and private homes, has common plaster and Pietraforte, with elements in artificial Pietra Serena and artificial Pietraforte. The building Canto dei Giugni, now used for dwellings and restaurants, consists of common plaster in the upper part of the façade and Pietraforte in the lower part, with ornamental elements in Pietra Serena and Pietra Bigia. Palazzo Uguccioni (16th century), attributed to Mariotto di Zanobi Folfi, was built entirely in Pietraforte with Pietra Serena and common plaster parts. Casa del Garbo (12th-19th century), at present used as homes and restaurants, shows a façade covered with common plaster with decorations in Pietra Serena and plaster (Bellucci, 2001; Jacorossi, 1972; Profeti, 1999) (Figures 1, 2).

The pavement of the square has consisted of different materials and colours throughout the centuries, starting from the original earthen soil to brickwork, to the Pietraforte and Pietra Serena of the 18 th century, to slabs in great part replaced with Pietra di Firenzuola in the eighties (20th century). 


\section{Palazzo Vecchio}

The building planned by Arnolfo di Cambio was built in 1299 as a new seat for the Priori delle Arti of the Florentine Republic (Bargellini, 1968).

The building stands on the remains of the preceding structures dating back to the Roman age (theatre whose cellars were used as prisons) as well as to medieval times: the houses of the Uberti family, defeated in 1258 , used to stand here. The original core, in the shape of a cube, was initially completed in 1302 and fully accomplished in 1315. The building was constructed as a fortress to resist and repel enemie assaults as can be seen by the thick ashlar walls and the high ironed windows of the ground floors. The building was divided into three storeys by thin frames. It presents a double row of mullioned round arched windows in gothic style. The crowning has a jutting-out gallery with covered and uncovered communicating corridors protected by strong merlons and held by brackets linked to round arches. The polychrome coats of arms of the Florentine Republic were painted under small arches. On the right stands the 94 metres high tower, built on top of the pre-existing Foraboschi or della Vacca tower, where Cosimo il Vecchio and Girolamo Savonarola were imprisoned. In the 15th century, it became the seat of the Signoria. In 1540, it was the mansion of the dukes until Cosimo I moved his court to the Palazzo Pitti and the building was given the name of Palazzo Vecchio. From 1865 to 1871, it housed the Italian Parliament when Florence became the capital of the newly united Italian Kingdom. Now it is the seat of the City Hall.

The main façade of the western side of the palace is mostly built in Pietraforte carved as little ashlars with elements in common plaster and corbels in Pietra Serena. The covered communicating corridor of the gallery is made of decorated plaster, the mullioned windows are of white statuario marble, and the decorating elements above the main entrance door are of glazed earthenware. The façade on the northern side standing on Via dei Gondi is mainly built in Pietraforte with elements in common and decorated plaster; the mullioned windows are in some cases in statuario marble or in plaster which imitates marble. The battlement placed below is built in a mixed material consisting of limestone, earthenware, Pietraforte and Pietra Serena.

Pietraforte is a sandstone belonging to the turbiditic formation present in the allocthonous complex of the External Liguridi superposed on the Tuscan Series. The formation dates back to the Upper Cretaceous (Abbate and Bruni, 1987; Bortolotti, 1962). Between Florence and Civitavecchia, it crops out in three areas (Florence, Amiata and Tolfa mountains), presenting different thicknesses. In the neighbourhood of Florence, Pietraforte consists of great lenses of turbiditic materials mostly at the base of the Sillano Formation. Thickness varies from $100 \mathrm{~m}$ to about $800 \mathrm{~m}$. From a lithological point of view it is a regular alternation of grey sandstone layers and argillites (hemipelagites) with rare intercalations of marls and marly limestones.

Petrographically, Pietraforte is a fine-grained $150 \mu \mathrm{m}$ lithic sandstone made in the same proportion by silicatic grains (quartz, feldspars and magmatic fragments) and carbonatic grains (dolostones). The grains are bounded by a mainly calcitic matrix that makes the rock particularly strong. Its porosity is $4-6 \%$. The mechanical parameters are higher than those of Pietra Serena thanks to the greater compactness established in the stone by the recrystallization caused by diagenesis; the maximum stress determined perpendicular to bedding is of about $140 \mathrm{MPa}$ (Cipriani and Malesani, 1966; Bruni et al., 1994).

In fresh cut the sandstone has a grey colour, but is easily oxidised acquiring an ochre brown colour on buildings. Such change in colour, due to the oxidation of iron, proceeds very quickly from the surface to the inside, without cohesion decrease.

Pietraforte is often characterized by laminations of a convolute type and by the presence of calcite veins which may stand for preferential areas of block detachment.

The most ancient quarries of this material were on the left side of the Arno river (e.g. Piazza Santa Felicita, Costa San Giorgio, Boboli, etc.). These quarries were later incorporated by the urban expansion and new ones were opened further south (Monteripaldi, Florence).

Nowadays the stone is quarried in the surroundings of Greve and in the quarry of Riscaggio, east of Florence.

Pietra Serena belongs to the sandstones of the Macigno Formation. It consists of beds of turbiditic sandstones separated by pelitic levels which are the finest components of single turbidity current. The Macigno which constitutes the upper part of the Tuscan Nappe, can be dated to the late Oligocene and stratigraphically overlies the Scisti Policromi. It has the greatest thickness along the alignment of Mt. Orsaro-Chianti Mts. where it can reach $3,000 \mathrm{~m}$.

Petrographically, this sandstone can be defined as a mediumcoarse-grained greywacke made by quartz, feldspars, micas, fragments of metamorphic and magmatic rocks. The matrix is quite abundant and is made by illite, kaolinite and chlorite-vermiculite (present only in some outcropping areas) (Cipriani and Malesani, 1963).

The grain size of the material used in architecture varies from medium fine to medium, with values around $250-300 \mu \mathrm{m}$. It shows a porosity varying from 4 to $6 \%$. It has a very high imbibition capacity and its saturation index can reach $80 \%$.

The mechanical parameters are relatively poor, the maximum stress in the best qualities, determined perpendicularly to bedding, is of about $70 \mathrm{MPa}$.

Pietra Serena has a bluish-grey colour in fresh cut, while under strong alteration, owing to the iron oxidation, it takes on an ochraceous colour different however from that of Pietraforte.

Pietra Serena seldom shows sedimentary structures such as parallel laminations. In addition, the veins of spathic calcite, due to the filling of pre-existing fractures, making up preferential detachment surfaces, are rather rare. It is owing to the rarity of these sedimentary structures and to the high workability that this stone is one of the materials most widely used in Florentine architecture for decoration purposes.

The most ancient quarries of Pietra Serena were probably located even in Roman-Etruscan times in the Fiesole ridge. Periods of greater development of quarrying of this stone can be dated between the 13 th-15th centuries, both bound to the urban growth of the city. In the 13th century, the quarrying activity was carried out in areas around Fiesole (Valle del Mugnone, Monte Ceceri, Vincigliata, Settignano); while in the 15th century new quarries were opened, for example, to the west (Gonfolina and Carmignano) and to the south of Florence (Tavarnuzze), to meet the great demand for this material during the Renaissance. Nowadays the quarrying of this stone around Florence has almost ceased, except for the quarry at Caprolo near Greve, $25 \mathrm{~km}$ south of Florence and at Ponte di Mezzo near Lastra a Signa, about 20 km west of Florence (Banchelli et al., 1997).

\section{Historical introduction to the Cathedral of Santa Maria del Fiore}

From the laying of the first stone of the Cathedral of Santa Maria del Fiore on September 8, 1296 to its dedication and structural completion in 1436, famous architects such as Arnolfo di Cambio, Giotto, Francesco Talenti and Filippo Brunelleschi, just to mention a few, were involved in its construction one after another leaving enduring marks of their architectural expressions. The external decoration of the Cathedral was entrusted to Arnolfo di Cambio, who created the first project. Arnolfo carried out a decoration with a trichromy obtained using "white", "red" and "green" Tuscan "marbles", which recalled on one side the mosaics of the Roman cloisters of San Paolo in Laterano and on the other the Florentine tradition that had significant examples in the Battistero and in the façade of San Miniato al Monte. When Arnolfo died (March, 1301), all the walls had already been put up and the marble decoration, so well appreciated by those who carried on his work, was started and extended to the whole building. The setting up of the marble faces 


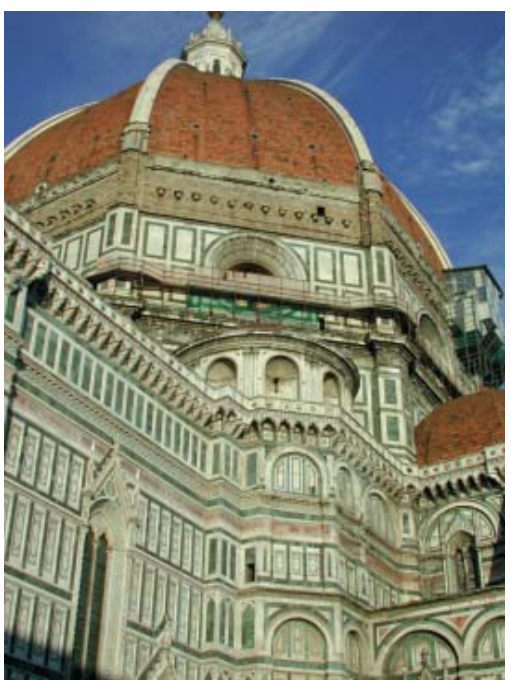

Figure 3 A panoramic view of the Florence Cathedral. went on with the construction of the walls. This aspect is indirectly confirmed by the resolution of November 19, 1367 in which the setting up of the marble faces was to be postponed to give priority to the building of the walls (Figure 3).

The dedication of the Cathedral, completed in its structure, took place in 1436 when many parts were still unfinished, such as the lantern, completed in 1470, after Brunelleschi's death. The façade planned by Emilio De Fabris was inaugurated in 1887 while the sheathing of the tambour of the Dome was still unfinished.

\section{Materials used in the original construction and for the façade}

Information on the materials used in the originally setting up of the Cathedral can be drawn from many archive documents kept at the Library of Opera del Duomo in Florence.

Cesare Guasti (1887) in his "Santa Maria del Fiore-La costruzione della Chiesa e del Campanile secondo i documenti tratti dall'archivio dell'Opera Secolare e da quelli di Stato" relates the resolution of the Opera dated January 5, 1350 confirming the lithotypes making up the trichromy of the Cathedral.

The entire bibliography leads to the conclusion that the "red", marly limestones of San Giusto di Monterantoli (Cintoia in Chianti mountain) were used for the original construction of the Cathedral, as well as marly limestones from Monsummano in Valdinievole (Pistoia), Carrara marbles for the "white", and serpentinite from Figline di Prato (Prato) for the "green".

There is a difference in the case of the façade which was built later: the "green" of serpentinites coming from Figline di Prato was used along with the "red" coming from several quarries, above all in the Grosseto area, at Villa Collemandina (Garfagnana-Lucca), at Monsummano and in the Perugia area; while for the "white" after several visits to Carrara and Serravezza an agreement was reached with G.B. Sancholle Henraux who provided the marble from his quarries at Serravezza (Lucca) at cost price (AA.VV., 1987) (Figures 4a, b).

\section{The "red"}

A preliminary microscopic exam of the "red" used in the side faces of the original construction of the Cathedral showed the presence of two different typologies. In the literature and archive documents, there wasn't unanimous agreement on the provenance of the material, but several works of research carried out in recent years
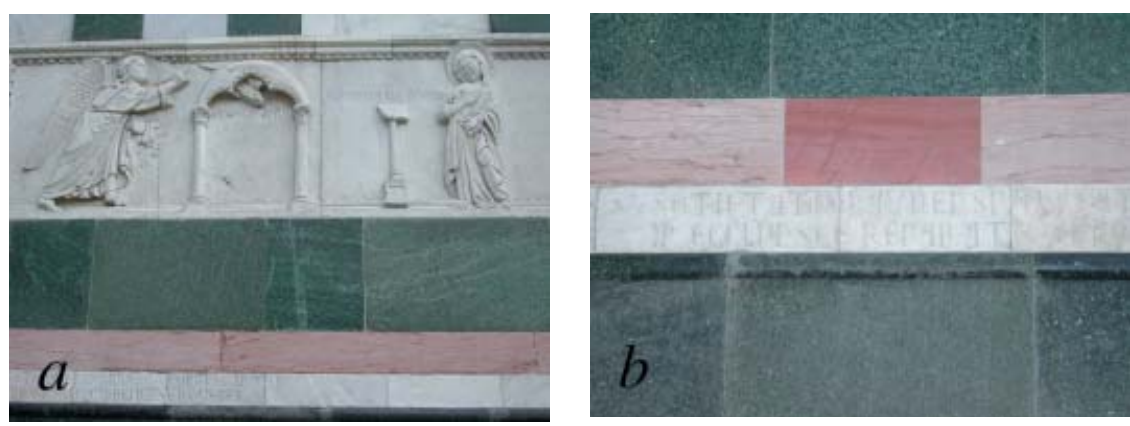

Figures 4a,b A detail of the trichromy of "marbles" in the façade.
(Sartori, 1996; Vannucci et al., 1997; Fazzuoli et al., 1998; Sartori, 1998) have led to an exact lithological identification. The "reds" have been therefore attributed to the Marls Formation of Sugame of the Tuscan Series cropping out at S. Giusto a Monterantoli (Cintoia in Chianti mountain) and to the Marls Formation of Sugame cropping out at Monsummano (Pistoia). Research carried out both on the "reds" present in the side façades of Santa Maria del Fiore and on Santa Maria Novella, as well as on the columns of the Grotta Grande in the Boboli Gardens, have led to the determination of a series of mineralogical and geochemical parameters able to identify the lithotype employed and, in some cases, the sites of supplying.

It must be also specified that the main lithotypes of the Marls Formation of Sugame, cropping out at Cintoia, consist of violet-reddish, liver-red, greyish pink, light olive grey marly limestones, sometimes not stratified, with a scaly fracturing. The same litofacies of the Marls Formation of Sugame cropping out at Monsummano, having a higher thickness than that of Cintoia, is almost entirely non-stratified.

Moreover, the "reds" from Monsummano show two different lithologies. The first consists of liver-reddish marly calcilutites with frequent bioturbations and fractures filled with calcite. Their appearance is very close to that of the marly limestones from Cintoia and is in agreement with Agostino Del Riccio's description (Del Riccio, 1597). In the second case, they look like nodular limestones as they have more or less amygdaloid forms made by lighter micritic limestone surrounded by a redder marly limestone. This has a consequence of boundinage phenomena due to plastic imperfections in the originary deposit (Fazzuoli and Maestrelli Manetti, 1973).

These lithotypes are characterized by a content in calcite that goes from 79 to $87 \%$ and a content in quartz from 6 to $13 \%$ often prevailing on the phyllosilicates; the feldspars are represented only by plagioclases.

Among geochemical parameters the content in barium appears, at least in most of the samples, quite discriminating according to the provenance. At Cintoia the average content is around $1100 \mathrm{ppm}$ against an average content of about $140 \mathrm{ppm}$ in Monsummano.

The association of clay minerals that characterize the two lithotypes (both at Cintoia and at Monsummano) consists, in order of abundance, of illite, kaolinite, chlorite and chlorite-vermiculite.

As concerns physical characteristics, porosity ranges between 2 and $3.5 \%$. The absorption in water is low with a saturation index generally lower than $35 \%$.

As to the façade several types of "reds" have been noticed: nodular limestones rich in ammonites coming from several Tuscan areas (Gerfalco, near Grosseto and Monsummano near Pistoia) and marly micritic limestones coming from Montieri (Grosseto), Villa Collemandina (Garfagnana-Lucca) and Monte Malbe-Perugia (Red Scaglia Formation in the Umbria Series).

The nodular limestone, rich in ammonites, appears as micrite whose nodules are delimited by the presence of discontinuities of irregular course filled by iron oxides. Micritic limestones turn out to be rich in calcite veins characterized by a greater content in oxides present both in the mass and concentrated in thin levels.

\section{The "white"}

The white of the original construction of the cathedral sides is marble coming mostly from the Apuan Alps as well as the Montagnola Senese.

Apuan marbles formed during the Oligocenelower Miocene (27-10 m.y.) at temperatures of $350^{\circ}-450^{\circ} \mathrm{C}$ and pressures of 5-6 kbar (Di Pisa et al., 1985; Schultz, 1996; Franceschelli et al., 1997). Several varieties have been identified among the marbles, some deriving directly from the original sedimentary lithologies preserving some of their texture patterns (common white marble used in the Cathedral's faces), others originating through pliable interdigitation between two different lithologies, such as Arabescato and Nuvolato varieties.

Common white marble can present several typologies; from white (statuary type) to more or less veined. Compositionally it consists of $99 \%$ cal- 
cite and traces of quartz, albite, muscovite and pyrite. Common marble can also show microstructures varying from polygonal granoblastic with rectilinear contacts between grains, to xenoblastic with suturated contacts between grains (Coli, 1989; Molli et al., 1997; Meccheri and Molli, 1996). The size of the grains generally ranges between 200 and $500 \mu \mathrm{m}$, while their porosity varies from a minimum of about $1 \%$ for the xenoblastic structure to a maximum of $2.5 \%$ for the polygonal granoblastic structure (Barsottelli et al., 1998).

Marbles from the Montagnola Senese have colours that go from white at the base of the sequence (the variety present in the Cathedral) to greyish, while at the roof they take over a pink to yellow shade (Giannini and Lazzarotto, 1970; Micheluccini et al., 1981). These marbles formed in the same period as the Apuan marbles, but under much lower temperature conditions. The recrystallization processes were milder and the average size of the grains turns out to be smaller than that of Apuan marbles (50-150 $\mu \mathrm{m})$.

The marbles of the façade, even if coming from the same quarries as those of the side faces, show a mainly granoblastic structure characterized by the presence of rectilinear contacts between the grains. This has caused a greater decay in time that leads to the need of many replacements.

Instead the marbles of the sides show structural characteristics mostly referable to a xenoblastic microstructure, characterized by contacts between calcite granules, lobated or suturated that can give the blocks a considerable durability.

\section{The "green"}

The "green" used in the original construction of the Cathedral is a serpentinite, a lithotype originated from oceanic metamorphism of peridotite (composed of olivine and pyroxenes) with a consequent formation of serpentine (Wick and Wittaker, 1997). These rocks are present, even if in outcroppings of limited extensions, mostly in the Northern Apennine and make up the so called Ofiolitic Complex in which gabbros and basalts are always found associated. Serpentinite is characterized by a considerable mineralogical homogeneity, but the rocks show varieties with very different colours and macro and microscopical structures. Many shades of green can be found on the Cathedral, from light to dark till almost black, sometimes with bluish reflections often spotted with stains.

The macroscopical structure of serpentinite can be relatively uniform, interrupted by small whitish veins of fibrous serpentine (chrysotile) or characterized by a thick interlacement of light veins as in the "ranocchiaia" variety.

Two varieties are distinguished at a microscopical level: the first is characterized by the presence of variable percentages of bastitic texture, mesh texture and hourglass texture. Bastites are the relics of the serpentinization of amphiboles and pyroxenes, whereas mesh texture and hourglass texture are the relics of the serpentinization of olivine. All these textures are constituted by lizardite type serpentine; while the rare veins are made of chrysotile type serpentine. The presence of magnetite in small crystals is widespread; chromiferous spinel and pyrite are also present.

Hourglass texture prevails in the second variety with a small percentage of bastite and the absence of mesh texture. Magnetite is present in grains, which are larger in size than those of the former variety. This determines a light green colour in the rock. The tiny chrysotile veins can be so plentiful as to reach a thick interlacement that characterizes the "ranocchiaia".

Concerning petrophysical characteristics, it has been noticed that the Apennine serpentinites at lizardite+chrysotile, having a porosity ranging between 3 and $10 \%$, are characterized by a saturation index often greater than $100 \%$, which causes strong problems of durability (Fratini et al., 1987, 1991; De Vecchi et al., 1991; Bralia et al., 1995).

As to the façade, the "green" is always the Appeninic serpentinites.

\section{Materials employed in replacements}

Most of the replacements and/or restorations were performed on marble used in greater quantity and making up most of the modelling, subject to a stronger decay, unlike the faces that always turn out to be better preserved. Replacements on the "red" were fewer and still fewer on the "green".

It can reasonably be inferred that the quarries furnishing the white marble, the red marly limestones and the serpentinite, when necessary, have remained the same for economical and practical reasons, at least up to the first years of the twentieth century: the marble quarries were in the Apuan Alps, those of marly limestones at San Giusto a Monterantoli and Monsummano and that of serpentinite at Figline di Prato. In recent years, except for the Apuan marble, the "red" and the "green" quarries were closed both to safeguard and protect the environment and to avoid depletion of the materials; other quarries were identified: the "red" has changed with the micritic limestone of Villa Collemandina and the "green" comes from the Alpine area (Val Malenco) (Bianchini, 1999). The "Alp green" of Val Malenco is a serpentinite where the high pressure metamorphism changed the chrysotile and lizardite in antigorite.

The use of marble from the Montagnola Senese has no longer been reported from information gathered at the Opera del Duomo.

\section{Conclusions}

In this paper geolithology and provenance of the materials of some historical buildings of Piazza della Signoria and of the monuments of Piazza del Duomo have been considered.

In Piazza della Signoria two sandstones are mostly used: Pietraforte, as building material and Pietra Serena in the architectonic elements. Moreover, the use of other materials such as marbles, decorated plasters, glazed earthenware can be seen in the decorative elements. As to provenance of the sandstones, the ancient quarries of Pietraforte were on the left side of the Arno river (south of the city), while the ancient quarries of Pietra Serena were in the Fiesole ridge (north of Florence).

Concerning the Cathedral of Santa Maria del Fiore it is necessary to distinguish the lithotypes of the original construction and the more recent façade. The original setting up is constituted by a trichromy: a red limestone, a white marble and a green serpentinite. The "red" is a marly limestone quarried at San Giusto di Monterantoli (Cintoia in Chianti mountain) and at Monsummano in Valdinievole (Pistoia), the "white" is a common Carrara marble quarried in the Apuan Alps and the "green" is a serpentinite from Figline di Prato (Prato).

The same colours are present in the façade, but the "red" is a marly limestone coming from several quarries, above all in the Grosseto area, at Villa Collemandina (Garfagnana-Lucca), at Monsummano (Pistoia) and in the Perugia area; the "white" is a common marble coming from Serravezza (Lucca); while the "green" of serpentinites is the same as the original construction.

\section{References}

AA.VV., 1987, Due granduchi, tre re e una facciata: Alinea Ed., Firenze.

AA.VV, 1993, Le pietre della città d' Italia: Atti della Giornata di Studi in onore di Francesco Rodolico, Firenze 25 Ottobre 1993.

Abbate, E., and Bruni, P., 1987, Modino-Cervarola. Torbiditi oligo-mioceniche ed evoluzione del margine nord appenninico: Mem. Soc. Geol. It. 39, pp.19-33.

Allegri, E., and Cecchi, A., 1980, Palazzo Vecchio e i Medici: Guida storica, Firenze.

Banchelli, A., Fratini, F., Germani, M., Malesani, P., and Manganelli Del Fà, C., 1997, The sandstones of Florentine historic buildings: individuation of the marker and determination of the supply quarries of the rocks used in some Florentine monuments: Science and Technology for Cultural Heritage v. 6, no. 1 , pp. 13-22.

Bargellini, P., 1968, Scoperta di Palazzo Vecchio, Firenze.

Bargellini, S., McGoldrick, M.P., La Cagnina, S., Jacorossi, M., 1970, Tutta Firenze ieri ed oggi: Ed. Tornatre.

Bargellini, P. and Guarnieri, E., 1985-1987, Le strade di Firenze: Firenze, v. 5, pp. 212.

Barsottelli, M., Fratini, F., Giorgetti, G., Manganelli Del Fà, C., and Molli, G., 1998, Microfabric and alteration in Carrara Marble: a preliminary study: Science and Technology for Cultural Heritage, v. 7, no 2, pp. 115-126.

Bellucci, B., 2001, Geolitologia del costruito del centro storico di Firenze e provenienza dei materiali. Tesi di Laurea inedita, Università degli Studi di Firenze, Anno Accademico 1999-00. 
Bianchini, P., Fratini, F., Manganelli Del Fà, C., Pecchioni, E., and Sartori, R., 1999, Sette secoli di manutenzione programmata per la conservazione dei paramenti lapidei della Cattedrale di Santa Maria del Fiore in Firenze, in Atti del Convegno di Studi Scienza e Beni Culturali XV, Ripensare alla Manutenzione: ricerche, materiali, tecniche per la cura del costruito, Bressanone 29 Giugno-2 Luglio 1999, Ed. Arcadia Ricerche, pp. 231-242.

Bortolotti, V., 1962, Contributo alla conoscenza della Serie Pietraforte-Alberese: Boll. Soc. Geol. It., v. 81, no. 2, pp. 225-304.

Bralia, A., Ceccherini, S., Fratini, F., Manganelli Del Fà, C., Mellini, M., and Sabatini, G., 1995, Anomalous water absorption in low grade serpentinites: more water than space?: Eur. J. Mineral., v. 7, pp. 205-215.

Bruni, P., Cipriani, N., and Pandeli, E., 1994, New sedimentological and petrographical data on the Oligo-Miocene turbidite formation of the Tuscan domain: Mem. Soc. Geol. It., v. 48, pp. 251-260.

Cecchi, A., 1995, Palazzo Vecchio. Firenze: Roma.

Cipriani, C., and Malesani, P., 1963, Ricerche sulle arenarie: 8) Determinazioni microscopiche sulle arenarie delle formazioni del Macigno e della Marnoso Arenacea: Periodico di Mineralogia v. 32, no. 2-3, pp. 343-345.

Cipriani, C., and Malesani, P., 1966, Ricerche sulle arenarie: 13) La Pietraforte: Boll. Soc. Geol. It., v.85, no. 2, pp. 299-332.

Coli, M., 1989, Litho-structural assemblage and deformation history of Carrara Marble: Boll. Soc. Geol. It., v. 108, pp. 581-590.

Del Riccio, A., 1597, Istoria delle Pietre: Ristampa a cura di P. Bazzocchi, S.P.E.S. Firenze, 1979 (2)

De Vecchi, G., Rossetti, M., and Vannucci, S., 1991, La serpentina della Cattedrale di Santa Maria del Fiore a Firenze ed il suo degrado, in Atti del Convegno Scienza e Beni Culturali: Le Pietre nell'Architettura: struttura e superfici, Bressanone 25-28 Giugno 1991, pp. 247-256.

Di Pisa, A., Franceschelli, M., Leoni, L., and Meccheri, M., 1985, Regional variation of the metamorphic temperatures across the Tuscanid I Unit and its implication on the Alpin metamorphism (Apuan Alps, North Tuscany): Neues Jahrbuch fur Mineralogie Abhandlungen, v. 151, pp. 197-211.

Fazzuoli, M., and Maestrelli Manetti, O., 1973, I nuclei mesozoici di Monsummano, Montecatini Terme e Marliana (Pistoia): Mem. Soc. Geol. It., v .12, pp. 39-79.

Fazzuoli, M., Sartori, R., and Vannucci, S., 1998, Le "Pietre" del Colle di Monsummano negli usi architettonici, in Il Colle di Monsummano Alto-Le Pietre e le Acque. Aspetti geologico-ambientali, Ed. Pacini, pp. 86-87.

Franceschelli, M., Memmi, I., Carangiu, G., Giannelli, G., 1997, Prograde and retrograde chloritoid zoning in low temperature metamorphism, Alpi ApuaneItaly: Schweiz Mineral. Mitt., v. 77, pp. 41-50.

Piergiorgio Malesani, Full professor of Petrography at the Faculty of Mathematical, Physical and Natural Sciences of the University of Florence since 1976. Member of the Scientific Council of the "Centro di Studio sulle Cause di Deperimento e sui Metodi di Conservazione delle Opere d'Arte-CNR-Firenze". His scientific interest includes Applied Petrology, Conservation of Cultural Heritage, Sedimentary and Magmatic Petrology and Engineering and Regional Geology.

Elena Pecchioni, Researcher in Petrology applied to Conservation of Cultural Heritage at Earth Science Department of University of Florence. Specialized in Science applied to Conservation of Cultural Heritage. Her scientific interest are weathering and conservation of natural and artificial stone. She teaches Applied Petrology and Mineralogy at the Restoration School of Opificio delle Pietre Dure of Florence.

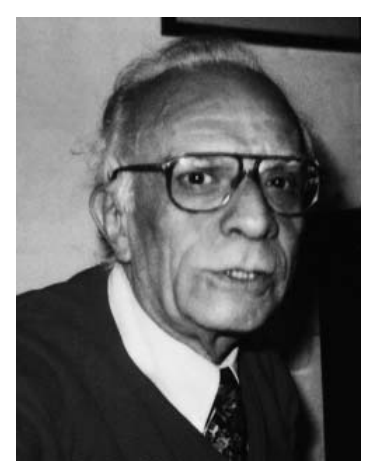

Fabio Fratini, Researcher in Petrology applied to Conservation of Cultural Heritage at the National Council of Researches (C.N.R.) of Florence. He carries out researches on natural and artificial stone materials, archeometry and conservation.

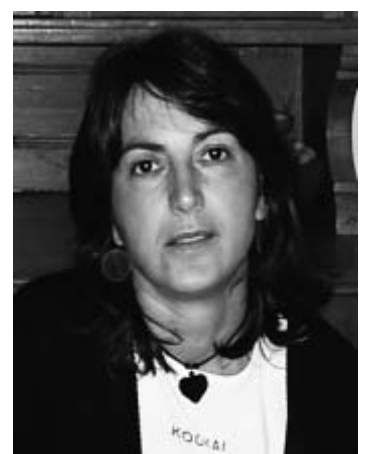

Emma Cantisani Graduated in Applied Petrology in 1999 at the Earth Science Department of Pisa University, attending a PhD Course in Science for the Conservation of Cultural Heritage at Florence University.
Fratini, F., Manganelli Del Fà, C., Tiano, P., Matteoli, U., and Camaiti, M., 1987, Indagini conoscitive sullo stato di conservazione dei materiali lapidei presenti sulla facciata di S. Maria del Fiore, Firenze: in Due granduchi, tre re e una facciata, Alinea Ed., Firenze, pp. 66-78.

Fratini, F., Ceccherini, S., Pecchioni, E., Manganelli Del Fà C., Scala, A., and Galletti G., 1991, Alterazione del marmo e della serpentinite costituenti il rivestimento della facciata della Collegiata di S. Andrea in Empoli (Firenze), in Atti del Convegno Scienza e Beni Culturali: Le Pietre nell'Architettura: struttura e superfici, Bressanone 25-28 Giugno 1991, pp. 323-334.

Giannini, E., and Lazzarotto, A., 1970, Studio geologico della Montagnola Senese: Mem. Soc. Geol. It., 18.

Guasti, C., 1887, S. Maria del Fiore, La costruzione della Chiesa e del Campanile secondo i documenti tratti dall'Archivio dell'Opera Secolare e da quello di Stato: Arnoldo Forni Editore, Firenze 1887

Meccheri, M. and Molli, G., 1996, Nuove conoscenze dei Marmi del Carrarese (abs), in 78a Riunione estiva della Società Geologica Italiana, San Cassiano (Bz), 16-18 Settembre 1996.

Micheluccini, M., Moretti, A., Panti, F., and Cartei, B., 1981, I marmi della Montagnola Senese: Amministrazione provinciale di Siena.

Molli, G., Heilbronner Panozzo, R., and Wittensoldener, V., 1997, Microstrucural features of naturally deformed Alpi Apuane marbles: an introduction (abs): Conference on Deformation Mechanism in Nature and Experiments, Basel, March 17-19 1997, pp. 45-46.

Jacorossi, M., 1972, I palazzi fiorentini. Quartiere di San Giovanni: Firenze.

Profeti, C., 1999, I palazzi di Firenze, Firenze, pp. 72-77.

Sartori, R., 1996, Caratteristiche petrografiche e provenienza dei "marmi rossi" nell'architettura fiorentina: Tesi di Laurea inedita, Università degli Studi di Firenze, Anno Accademico 1995-96.

Sartori, R., 1998, I "marmi rossi" delle colonne della Grotta Grande in Boboli: Atti del Convegno Internazionale di Studi Artifici d'Acqua e Giardini: la cultura delle Grotte e dei Ninfei in Italia ed in Europa, a cura del Ministero Beni Culturali ed Ambientali, Firenze Palazzo Pitti 16-17 Settembre 1998, Centro Di Editore Firenze, pp. 294-296.

Schultz, H., 1996, Analyse der variszisch apenninischen deformationgeschichte des paläozoischen Basament der Apuaner Alpen (Toskana, Italien): Berlinen Goewissenschafteliche Abhandlungen, pp. 188, 198

Vannucci, S., Sartori, R. and Fazzuoli, M., 1997, I “marmi rossi” dell'architettura policroma fiorentina: in Kermes Arte, Conservazione e Restauro, no. 30, Settembre-Dicembre 1997.

Wicks, F.J., and Whittaker E.J.W., 1997, Serpentine textures and serpentinization: Canad. Mineral., v. 15, pp. $459-488$
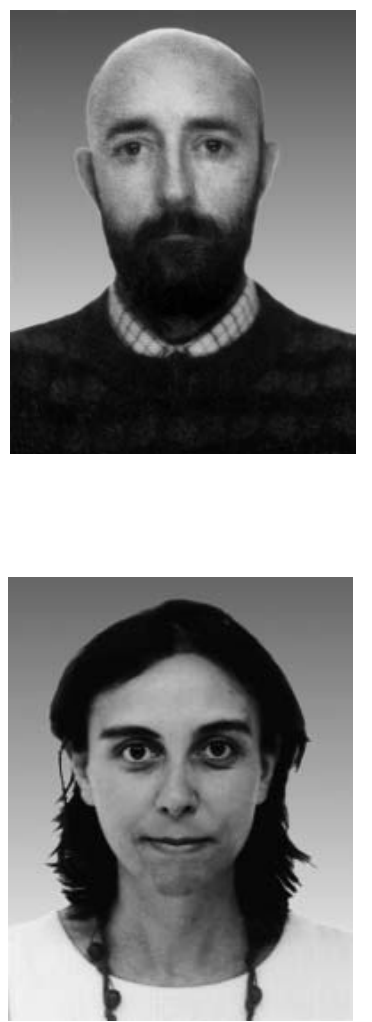